\title{
Business Organization
}

National Cancer Institute

\section{Source}

National Cancer Institute. Business Organization. NCI Thesaurus. Code C54128.

A structure through which enterprises cooperate systematically to conduct activities for profit. 